\title{
Strategic Repositioning of Koforidua Polytechnic
}

\author{
Samuel Okae-Adjei \\ Department of Marketing, Koforidua Polytechnic, P.O.Box 981, Koforidua, Ghana \\ E-mail: yaresammy1964@yaboo.com
}

\begin{abstract}
The study seeks to find out what changes are taking place in strategy in Koforidua Polytechnic and why? The methodology used in the study is based on qualitative approaches of documentary analysis. Data is collected through a content analysis of relevant documents. The scope of the study is limited to the researcher's interpretation of the strategic changes identified and articulated in official polytechnic documents. A framework for assessing and modeling changes in strategy provided by Ginsberg (1988) is adapted to suit the higher education context and applied in the analysis. The adapted framework is used as a tool to conceptualize changes in strategy in Koforidua Polytechnic. The findings indicate significant changes in strategy in Koforidua Polytechnic. The leadership of the polytechnic has introduced new strategic directions for the polytechnic, focusing on the provision of infrastructure facilities, improving financial resource mobilization, promoting research, strengthening collaborative partnership at home and abroad, and promoting good governance and planning. External and internal conditions provide pressure for the shift in strategic direction. The change in direction is a necessary measure which ensures the future of the polytechnic.
\end{abstract}

Keywords: Strategy, Strategic change, Strategic planning, Higher education, Koforidua Polytechnic.

\section{Introduction}

The environment in which higher education institutions operate is changing at an unprecedented rate. For organizations to achieve their goals, they should be subject to change. There is, therefore, no doubt that it is important for any organization to have the ability to identify where it needs to be in future and how to manage the changes necessary to get there. The study and measurement of strategic change is very complex given the wide variation of definitions and conceptualizations that exist in relation to them. Strategic changes relate to the process of organization renewal and transformation which are influenced by the internal and external environment. It can simply be defined as a change in strategy. With this definition, the case study analyses the changes that have taken place in strategic planning within Koforidua Polytechnic since 2005.

Koforidua Polytechnic can respond to the inevitable evolution in the higher education system in two ways: ad hoc and strategic repositioning. Since the best way to predict the future is to invent it, this study is an attempt to find out whether or not the Polytechnic is taking conscious decisions and actions to shape its change and development. The study will find out what changes are taking place in strategy and why. What are the implications of these changes for the future of the Polytechnic?

\section{Literature review}

\subsection{Defining and measuring strategic change}

Scholars in the field of strategy have given different meanings to the term 'strategy'. Steiner et al. (1986) describe strategy as the forging of company's missions, setting objectives for the organization in the light of external and internal forces, formulating specific policies and strategies for the achievement of objectives for proper implementation so that the basic purposes and objective of an organization will be achieved. Many definitions of strategic planning appear in the jungle of literature available on this topic. According to de Lourdes Machado et al (2004; p33) strategic planning is a continuous process, an externally responsive approach to an ever-changing environment that requires constant adaptation on the part of the institution. It is described as a way of creating the future, as a process for organizational 
renewal and transformation which focuses on adaptive change or change motivated by the external environment.

A lot of models abound for the development of strategy in the literature. The abundance of literature makes it a challenging task for one to get an overall picture of strategy tools and models. Ward and Rivani (2005) have attempted to describe and systemically compare a selection of common models used. They describe the Boston Consulting Group (BCG) matrix, which dates back to the 1970's as based on the combination of two dimensions: Business Growth and Market Share. Porter's Five Forces Model (P5F) which is about competitive strategy is described as the provision an overall model to help enterprises realize the impact of external scenarios (forces) on their overall performance. The Ansoff Matrix which is concerned with market penetration, market development, product development and diversification is particularly strong in those enterprises where market pull is the predominant way of completion. The PEST analysis - Political, Economic, Social and Technological - is described as a framework used in the assessment of the external environment in which a company operates, and is based on the assumption that certain external and indirect circumstances that characterize an industry are able to influence its capacity to produce value (Ward and Rivani, 2005).

Mintzberg (1978) groups strategic decision making into three modes: planning, adaptive and entrepreneurial. The planning mode is a well organized, integrated process where strategies are illuminated in a timely fashion by a purposeful organization. Conversely the adaptive mode describes the process in which many decision makers with contradictory goals negotiate to produce a course of incremental, incoherent decisions. Finally the entrepreneurial mode depicts a process where a powerful leader takes bold, risky decisions based on his/her vision of the organizations' future.

There exist strategies that are intended and those that are realized unintentionally (Mintzberg, 1978). This difference makes the measurement of strategic change a complex and controversial matter. Snow and Hambrick (1980, cited in Ginsberg, 1988) challenge the researcher to consider at what point an organizational response to environmental change represents a change, as opposed to an adjustment in strategy. Two schools of thought exist, the 'content school using large samples and statistical methods to investigate the antecedents and consequences of strategic change and the 'process' school which uses longitudinal case studies to examine the role of managers in the strategic change process (Rajagopalan and Sprietzer 1997).

In the literature there are many technologies, models, theories and frameworks on change strategies. In the view of the strategic change literature, Rajagopalan and Sprietzer (1997) use the perspectives of the rational learning and cognitive theoretical lenses, and they discuss the theoretical and methodological contributions and limitations of each. In the rational lens perspective, strategic change is a sequential, planned search for optimal solutions for well-defined problems based on previously defined objectives. The learning and cognitive lens perspectives generally adopt the same definitions where strategic change is an evolutionary and iterative process and change is effective through a series of small adjustments in organizational and environmental conditions. While the rational lens perspective is found primarily in the content school, the learning and cognitive lens perspectives are mostly used in the process school of strategic change (p.50).

Ginsberg (1988) explains that where a strategic change occurs there is a change in certain particulars which can be described in terms of the content of the strategy and or the process of strategy making. He provides a framework for assessing and modeling changes in strategy which is employed later in the methodology of this paper. The framework involves an analysis of the factors that change when external scenarios or forces impact on overall performance.

\subsection{Drivers of organizational change}

In an effort for one to better understand why strategic changes occur in higher education, the factors that act as catalysts for change are examined. The literature reveals that many forces including global national, regional and local sources combine to drive change in contemporary higher education institutions. To succeed in this highly competitive environment, which is in constant state of flux, higher education institutions need to develop management capabilities, innovation strategies and competitive advantage (de Lourdes Machado et al, 2004)

For higher education institutions, strategic planning is shaped by external factors such as the higher education environment, national higher education policy and available resources on the one hand and by internal forces such as institutional culture, mission and vision on the other (Hayward and Ncayiyana, 2003). External challenges that require higher education institutions to reposition 
themselves all the time if they are to survive have been identified by Hayward and Ncayiyana (2003). They are: a shift to knowledge society, globalization; under resourcing; increased competition among institutions of higher education; the needs of a diverse and divided society, and the central role played by higher education institutions in national, regional and local development.

Skilbeck (2001) recognizes six forces that are driving change and impacting on higher education policies and practices globally: the growth in demand for higher levels of education attainment; the valuable economic returns to society on investment in higher education; the power of emerging knowledge; the rapid development of information and communication technologies; economic globalization and internationalization and the ongoing pursuit of cohesion, justice and equity in society. Among the most important environmental changes which affect higher education missions and strategies are fast growing internationalization and supra-national regional developments (Skilbeck, 1997).

The literature reports on many transformations arising from the Bologna (1999) Declarations at European level in the last decade (Eurydice, 2010; Gaston, 2010, Rauhvargers et al 2009). Higher education reform and development is being addressed at national level by the forty-seven countries whose Ministries have signed up to the Bologna Process. This process has been driving forward a reform to create European Education Area (CHEA) with more compatible, comparable and learner-centred transparent higher education systems. The Bologna process has turned access participation rates, graduates' employability, internationalization and lifelong learning into central concerns for participating countries (Sursock and Smidt, 2010).

In Ghana, national, cultural, political and economic factors influence change in higher education strategies. The economic downturn which made the government adopt the Neo-Liberalism Model of cost sharing in the higher education sector and the new Polytechnic Act of 2007 (Act 745), among others have contributed to strategic change in polytechnic institutions.

\subsection{Goodpractice in strategic planning}

With such a wide range of forces, from global to local, impacting on strategy formulation and implementation in higher education institutions, managers or leaders of Polytechnics have many factors to consider in their decision making process.
Strategic planning is strongly advocated in the literature as fundamental to superior system and institutional performance. Through their extensive review of literature de Lourdes Machado et al (2004) found and cited many ways in which strategic planning can be used to help organizations. These ways includes clarification of direction for the future, development of a coherent basis for the decision making process, establishment of priorities, improvement of organizational performance, promotion of institutional diversity, provision of clearer perspective of development options and thinking strategically.

Dooris (2004 cited by Pevzner, 2006) contends that an essential part of strategic planning is the shaping of the higher education institution to ensure that its mission is attained by the capturing and maintenance of a market niche in the pursuit of resources, staff and students. Skilbeck (1997) cautions institutions against emulation of models set by classical higher education institutions or by today's pace-setters. However, a certain isomorphism in the missions of higher education institutions may be unavoidable as they share external and internal features.

Much of the literature identifies the leaders of institutions as the central focus to strategic planning and a vital component of their success (de Lourdes Machado et al, 2004). As higher education institutions increase their understanding of the importance of planning there is a growing tendency of appointing Planning Officers to take charge of planning related activities.

\section{Methodology}

The methodology used in the study is based on qualitative approaches of documentary analysis which is appropriate for case studies (Yin, 1994). The two strategic plans of Koforidua Polytechnic are examined and comparatively analyzed. Data is collected through a content analysis of relevant documents. The sources of evidence used include strategic planning documents, minutes of the Governing Council and its sub-committees, reports of Rectors and direct observation. As an employee of the polytechnic, the researcher had access to the relevant documents: contact was made with the relevant departments for him to access all documents and information for this study. The focus is an analysis of changes in strategy with the research being fundamentally interpretive in its approach. Although the researcher is an employee of the polytechnic, every care was taken to analyze 
the documents as a neutral, unbiased observer.

Although surveys and interviews are commonly used in case studies involving higher education institutions, for this report, the researcher decided to focus on analysis of documentary evidence in order to identify changes in the polytechnic's strategy over the years. While interviews on a survey may reveal individuals' perceptions of what changes have taken place in the polytechnic and why, the scope of this study is limited to the researcher's interpretation of the strategic changes identified and articulated in official polytechnic documents.
The framework for assessing and modelling changes in strategy provided by Ginsberg (1988) (Appendix 1) is adapted to the higher education context and applied in the analysis. Ginsberg (1988) classifies the definitions of the term 'change in strategy' along two fundamental dimensions. The first dimension conceptualises strategy in terms of a position or a perspective. The second dimension conceptualises change in magnitude or pattern. This adapted framework (Table 1) is used as a tool for the conceptualization of changes in strategy in Koforidua Polytechnic. However, limitations in the scope of this study did not allow generation or analysis of data for all the factors identified in the framework.

Table 1

A framework for conceptualizing changes in higher education strategy (adapted from Ginsberg, 1988)

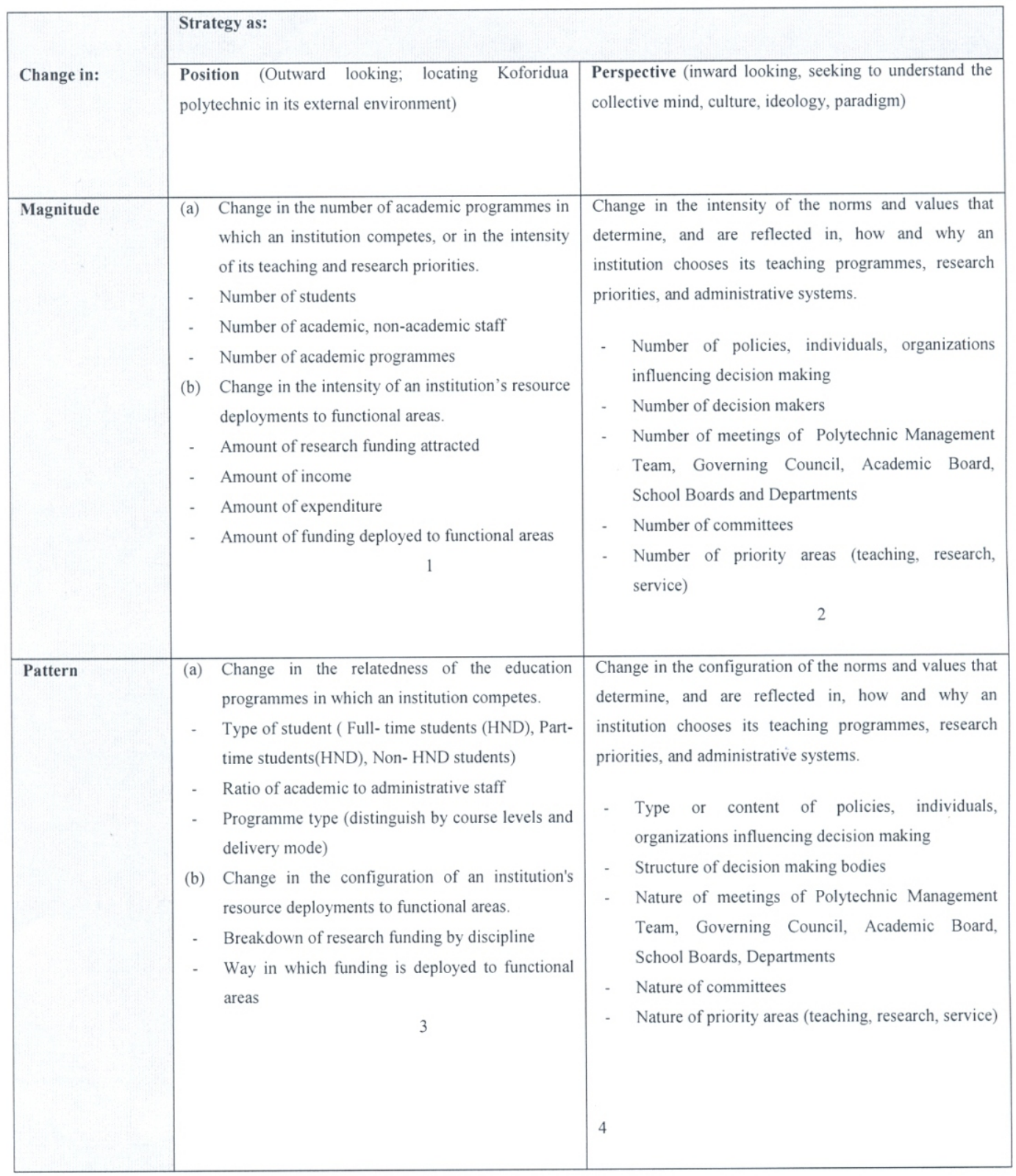


Appendix 1: Ginsberg ‘s Framework

\begin{tabular}{|c|c|c|}
\hline \multirow{2}{*}{ Change in } & \multicolumn{2}{|c|}{ Strategy as: } \\
\hline & Position & Perspective \\
\hline Magnitude & $\begin{array}{l}\text { (a) Change in the number of } \\
\text { businesses in which a firm } \\
\text { competes, or in the intensity of } \\
\text { its business specialization. } \\
\text { (b) Change in the intensity of a } \\
\text { firm's resource deployments to } \\
\text { functional areas. }\end{array}$ & $\begin{array}{l}\text { Change in the intensity of the } \\
\text { norms and values that determine, } \\
\text { and are reflected in, how and } \\
\text { why a firm chooses its business } \\
\text { domain, production processes, } \\
\text { and administrative systems. }\end{array}$ \\
\hline Pattern & $\begin{array}{l}\text { (a) Change in the relatedness of } \\
\text { the businesses in which a firm } \\
\text { competes. } \\
\text { (b) Change in the configuration of } \\
\text { a firm's resource deployments } \\
\text { to functional areas. }\end{array}$ & $\begin{array}{l}\text { Change in the configuration of } \\
\text { the norms and values that } \\
\text { determine, and are reflected in, } \\
\text { how and why a firm chooses its } \\
\text { business domain, production } \\
\text { processes, and administrative } \\
\text { systems. }\end{array}$ \\
\hline
\end{tabular}

The central research question regarding changes in strategy according to Ginsberg (1988) concerns the identification and explanation of the external and internal variables and associations which characterize the forces that signal disequilibrium in the behaviour of the organisation, or those that stimulate movement toward more effective and efficient behaviour. In the modelling and analysis of changes in strategy in
Koforidua Polytechnic, an attempt will be made for the researcher to find out the factor that influences the occurrence of various types of change in the institution. Also whether the performance outcomes of these various types of change are positive or negative will be known. The changes in strategy are interpreted by the use of the framework provided by Ginsberg (1988).

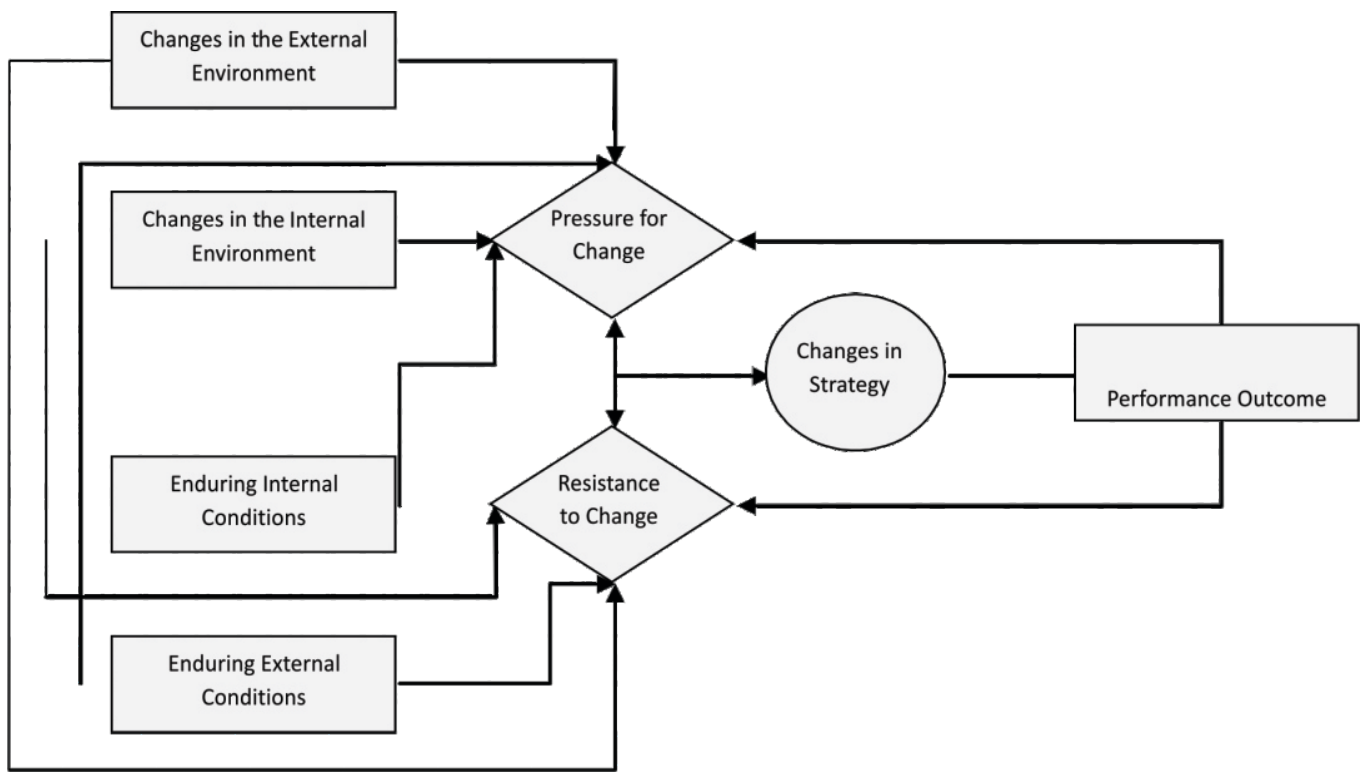

Fig.1: A framework for modelling changes in strategy 


\section{Findings and discussions}

\subsection{Strategicplan 2005-2009}

As a young institution, Koforidua Polytechnic has had two strategic plans: The first is the strategic plan of 2005-2009. The five-year strategic plan was to assist the Polytechnic to reposition itself as a first class tertiary institution in Information Technology Management in the Eastern Region and Ghana as a whole. This strategic plan was prepared through a consultative process with various stakeholders within and outside the Polytechnic. The planning process considered the strengths, desired strengths (weaknesses) opportunities and threats to the development of the plan. The strategic plan had a financial plan. The financial plan, which included an action plan, covered the Polytechnic's strategic thrusts, actions, expected outputs, costs, responsibility and time-frames. As an input to the achievement of the institutional vision and mission, eleven thrusts (thematic areas) were envisioned to ensure that the aims and objectives of the Polytechnic were achieved.

\subsection{Strategicplan 2010-2014}

This is the second strategic plan of the Polytechnic. This five-year strategy builds on the course set out in the first strategic plan. The plan seeks to consolidate the gains of the first strategic plan; continues with the changing projects from the previous plan, and re-strategizes the projects yet to be started to reflect the new direction of the Polytechnic. This plan is also meant to provide the broad road map for the Polytechnic in the achievement of its mission and vision. This strategic plan which takes into consideration the strengths, weaknesses, opportunities and threats of the Polytechnic, this strategic plan is guided by eight strategic thrusts.

\subsection{Comparative analysis of strategic plans}

A comparative analysis of the two plans shows a clear change in direction with only five of the strategic thrusts set out in the 2005-2009 Strategic Plan reflecting in the 2010-2014 strategic plan in figure 2. Thus only the strategic thrusts 2, 7, 8, 9 and 10 of the Strategic Plan of 2005-2009 are reflecting in the Strategic Plan of 2010-2014. Strategic thrusts 3, 7, and 8 of Strategic Plan 2010-2014 are new strategic directions of the Polytechnic.

\begin{tabular}{|c|c|}
\hline Strategic Thrusts & Strategic Thrust \\
\hline $\begin{array}{l}\text { 1. Create avenues for further studies in order to } \\
\text { provide opportunities for academic progression }\end{array}$ & $\begin{array}{l}\text { 1. Consolidating existing programmes and introduces } \\
\text { new ones as a way of attracting top class and highly } \\
\text { motivated students to the Polytechnic. }\end{array}$ \\
\hline $\begin{array}{l}\text { 2. Develop human resource capacities to improve } \\
\text { efficiency and effectiveness }\end{array}$ & $\begin{array}{l}\text { 2. Develop human resource capacities to improve } \\
\text { efficiency and effectiveness }\end{array}$ \\
\hline 3. Work towards achieving ideal staff: student ratios & $\begin{array}{l}\text { 3. Provision of infrastructural facility to enhance } \\
\text { teaching, learning and research }\end{array}$ \\
\hline $\begin{array}{l}\text { 4. Diversify modes of delivery to suit different } \\
\text { clientele }\end{array}$ & $\begin{array}{l}\text { 4. Harness ICT facilities for maximum efficiency and } \\
\text { effectiveness }\end{array}$ \\
\hline $\begin{array}{l}\text { 5. Leverage relationship with various stakeholders so } \\
\text { as to generate greater interest in programmes }\end{array}$ & $\begin{array}{l}\text { 5. Improve existing facilities to enhance academic work } \\
\text { and research }\end{array}$ \\
\hline $\begin{array}{l}\text { 6. Strengthen the applied nature of programmes } \\
\text { through approved research and communicating } \\
\text { service }\end{array}$ & $\begin{array}{l}\text { 6. Explore avenues for internally generated income } \\
\text { through provision of consultancy service and } \\
\text { continuing education }\end{array}$ \\
\hline $\begin{array}{l}\text { 7. Consolidate existing programmes as a way of } \\
\text { attracting top class, highly motivated students to } \\
\text { the Polytechnic }\end{array}$ & $\begin{array}{l}\text { 7. Improve financial resource mobilization and } \\
\text { management }\end{array}$ \\
\hline $\begin{array}{l}\text { 8. Harness ICT facilities for maximum effectiveness } \\
\text { in all areas of the Polytechnic's work }\end{array}$ & 8. Good governance and planning \\
\hline
\end{tabular}



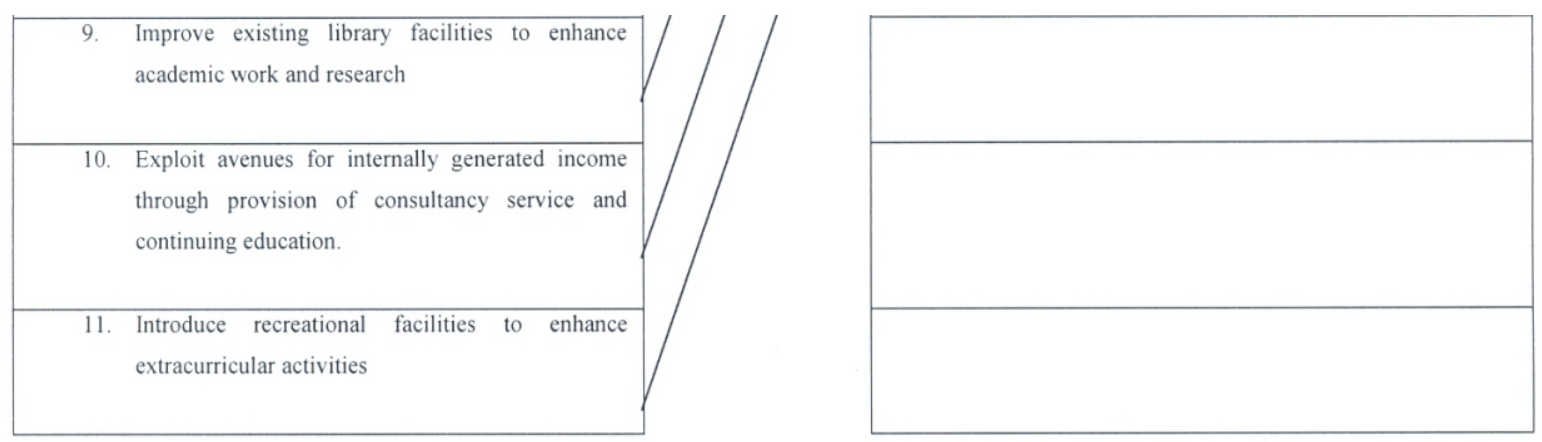

Fig.2: Polytechnic Strategic Thrust 2005-2009 versus Strategic Thrusts 2010-2014

\section{Change in position and perspective}

The change in position aspect of the framework for the conceptualization of changes in strategy is outward looking. It is concerned with the location of Koforidua Polytechnic in relation to its external environment and the changes in magnitude or pattern of the various components through which the polytechnic's with relationship with the environment is defined. The components examined for this case study include the number of students, staff, academic programmes, research findings, income and expenditure. These components are just a selection of the many relevant components that could have been added, but the collation of all impacting factors was beyond the scope of this study. The data in Table 2 was compiled from the information available in the reports of Rectors of the Polytechnic and through the contact made with the relevant administrative offices where necessary. A study of the Table shows that there is a significant change in the number of students, staff and programmes offered in the Polytechnic.

Table 2

Factors used to analyze change in position

\begin{tabular}{|c|c|c|}
\hline & 2005 & 2010 \\
\hline \multicolumn{3}{|l|}{ Students } \\
\hline Total students enrolled & 2208 & 4539 \\
\hline Full Time students (HND) & 1542 & 2379 \\
\hline Part-Time students (HND) Evening & 189 & 786 \\
\hline Non-HND students & 477 & 1374 \\
\hline \multicolumn{3}{|l|}{ Staff } \\
\hline Academic & 34 & 127 \\
\hline Non- Academic & 129 & 331 \\
\hline Total & 232 & 458 \\
\hline Academic Divisions/Schools & 2 & 3 \\
\hline \multicolumn{3}{|l|}{ Academic Programmes(HND) } \\
\hline Business and Management Studies & 3 & 4 \\
\hline Applied Science and Technology & 1 & 4 \\
\hline Engineering & 0 & 6 \\
\hline Academic Programmes (Non- HND) & 6 & 12 \\
\hline Total Research Funding & 0 & GH1 17,819.00 \\
\hline Total Income & GH? $1,538,719.26$ & GH? 8,485,752.69 \\
\hline Total Expenditure & GH? $1,048,882.75$ & GH? 7,220,753.13 \\
\hline
\end{tabular}


The change in perspective aspect of the framework for the conceptualization of changes in strategy is inward looking which seeks seeking to understand the collective mind, culture, ideology and paradigm. The change is concerned with integrated sets of ideas through which problems are spotted and interpreted and from which streams of decisions flow. The increasing in the number of departments in the Polytechnic from less than 10 in 2005 to more than 20 in 2010, changed the intensity of the norms and values that determined how and why the Polytechnic chooses its teaching programmes, research priorities, and administrative systems.

By increasing the number of departments and divisions (academic and non academic) and by empowering them to take decisions, the polytechnic attempt to devolve decision making to the individual division and departments, this devolution has streamlined the process by removing unnecessary bureaucracy and administrative layers.

The Planning Officer and the Development and Planning Sub-Committee of the Governing Council monitor and review the progress of the plan from time to time. The increase in the number of policies, meetings, committees, divisions, departments, and priority areas indicates a change in magnitude of perspective. The pattern of perspective is also changed owing to the change in the structure of decision making bodies and the nature of management meetings that takes place.

\section{Strategic changes}

In connection with the two strategic plans in conjunction with the other documents that were analyzed, five main changes in strategic direction emerge. These are:

1. The provision of infrastructural facility to enhance teaching, learning and research

2. Improvement in financial resource mobilization and management

3. The promoting of Applied Research

4. The establishment of collaborative partnerships at home and abroad.

5. Enhancement of good governance and planning.
6.1 First Strategic change: provision of infrastructural facility to enhance teaching, learning and research

External factors such as the growth in demand for higher level of education attainment and increased competition among institutions of higher learning have led to this strategic change. The Polytechnic is putting emphasis on infrastructural development to enhance teaching, learning and research. In 2001, a committee that was set up to examine Polytechnic education in Ghana described Koforidua Polytechnic as one of the least endowed Polytechnics. At that time one could talk about only a single two-storey block which housed the entire Polytechnic.

Although some infrastructural facilities have been put in place in the last decade, they are inadequate, when the current number of students and staff is considered. With the Polytechnics' new strategic direction, more infrastructural facilities are being provided.

The Polytechnic is completing a 27- unit block of flats for Senior Members/Senior Staff, 5- storey engineering block, and a 4- storey classroom/office block. The construction of the internal road network is already completed. The Polytechnic's strategic intension is to construct a student hostel, a maintenance/warehouse unit among others by 2014. This new strategic direction has led to a positive performance outcome.

\subsection{Second strategic change: improvement in financial resource mobilization and management}

One of the new strategic directions of the Polytechnic is improving financial resource mobilization and management. Consequently, the Polytechnic is making efforts to improve financial resource mobilization to meet academic objectives for recurrent activities and strategic investment in capital and staff. Efforts are also being made for the Polytechnic to achieve significant annual cost savings to take care of administrative activities and to develop the capital planning of the Polytechnic to ensure close alignment with academic priorities.

The pressure for change towards improvement in financial resource mobilization and management arises from the significantly changed external environment and enduring internal financial difficulties. The pressure to improve financial resource mobilization is also encouraged within national strategic goals. 
As the Polytechnic acknowledges its over dependence on the state for funding, its strategies are now geared towards more effort to the diversity of income sources. The underlying message to the staff is to generate income internally and ensure that corporate financial management; cost saving measures and effective capital planning are put in place.

The finding is consistent with the research carried out by de Lourdes Machado et al (2004) who identified twelve variables that contribute to the directions an institution may take, with one of the most influential being budgetary priorities. While the cost saving programme has impacted on the staff workload and necessitated sacrifices at departmental level, so far there is little evidence of resistance to the new fiscal policies. This attitude of less resistance indicates that the strategies taken to improve financial resource mobilization and management and to reduce dependence on the state have led to a positive performance outcome.

\subsection{Third strategic change: the promotion of applied research}

One of the new strategic directions of the Polytechnic is to promote research work. Research has not been given much attention since the Polytechnic was established in 1997. However, from available documents, the Polytechnic has now made Research one of its priority areas. The polytechnic has instituted an annual International Applied Research Conference. The conference was instituted in 2008 and by far four (4) conferences have been organized under various themes and more than one hundred (100) papers have been presented. Each School/Division has also set up an Applied Research unit.

The Polytechnic now has a Research Journal and has recently appointed a Director for Research. Fifteen (15) staff participated in international conferences and workshops between 2011/2012. The pressure for the institution to focus on research arises from both external and internal factors. Polytechnic institutions in Ghana are being urged to pay attention to research since they are supposed to play a central role in national, regional and local development. Internally, the research drive is encouraged by efforts to make Lecturers become Senior and Principal Lecturers. The focus on Research is also to enable the Polytechnic fulfill its vision and mission. This strategic direction has met no resistance and the performance outcome has been positive.

\subsection{Fourth strategic change: strengthening collaborative partnershipat homeand abroad}

The fourth change in strategic direction is the strong emphasis on strengthening collaborative partnerships at home and abroad, with particular attention on China. The Polytechnic is committed to links with the external environment through international, national and regional partnerships and collaborations with other higher education institutions and a wider range of stakeholders. The change in strategic direction is closely linked to the improvement in financial resource mobilization and so far there have been no evidence of resistance to it.

Difficult internal and external economic conditions provide pressure for the shift in strategic direction towards collaboration and external resourcing. Stronger partnership between the Polytechnic and the business communities are necessary to harness scientific and technological knowledge to drive national and regional competitiveness. The link with business in the provision of research capacity, consultation contracts, and continuous professional development, can result in additional funding, while enhancing the impact of Koforidua Polytechnic on national innovation.

Recently, the polytechnic has established institutional relationships with Plateau State Polytechnic of Nigeria, five Universities in China and Ghana Telecom University. These collaborations have brought several opportunities for staff exchanges and further investment and interest in Koforidua polytechnic. At the moment, nine (9) staff members of the Polytechnic are pursuing various degree programmes in China, enjoying tuition free scholarships. Two staff members of Plateau State Polytechnic are in Koforidua Polytechnic on an exchange programme and Ghana Telecom University has set up a campus at the Polytechnic to run Bachelors and Masters Degree programmes. All these indicate that this change in strategic direction has led to a positive performance outcome.

\subsection{Fifth strategic change: enhancing good governance and planning}

The fifth change in strategic direction identified is the emphasis on good governance and planning. With this strategy, the Polytechnic's strategic intent is to monitor progress in the implementation of strategies by Departments and Schools/Divisions. Efforts are in place to raise internal communication to a level to ensure consistent information flow. The Polytechnic constantly conduct programme reviews of academic 
decisions and develop planning of students' numbers, activities, buildings and facilities. The pressure on the Polytechnic to ensure good governance is due to internal and external factors. Among others the pressure arises from complaints of poor internal communication and the pursuit of justice, cohesion and equity in society. The performance outcome has been positive.

\section{Conclusion}

Strategic planning is a necessary measure for an institution to respond effectively to the changing expectations, demands, needs and emerging opportunities of the higher education market. Higher rates of participation, internationalization and the growing importance of knowledge-led economies and increased global competition together with global economic crisis have inspired international and national policy changes which have deeply altered the operation of higher education institutions. Koforidua Polytechnic has responded to the many pressures for change through setting out strategic thrusts (thematic areas). The polytechnic has taken the process of planning very seriously, requiring all departments to set up their own key action plans and targets.

Higher education institutions in Ghana are under pressure to achieve higher levels of quality, efficiency and effectiveness while maintaining creative and flexible environments for staff and students. In recent years, the higher education environment has been characterized by heightened uncertainty and apprehension regarding funding and future status.

The creation of more departments in Koforidua Polytechnic has encouraged a renewal emphasis on devolved planning within the new structure and empowered every department to contribute to the planning process. Against the milieu of the Polytechnic current and historical position, the leadership of the Polytechnic, who are the architects of the change effort in the institution, introduced new strategic directions for the Polytechnic which focus on the provision of infrastructural facilities, improvement of financial resource mobilization, promotion of research, strengthening collaborative partnership at home and abroad and good governance and planning.

This more focused business-like approach to planning and decision-making, which is underpinned by relevant academic theory, shows that Koforidua Polytechnic is ticking all the right boxes in good practice as identified by skilbeck (1997). This planning includes identification of a vision and mission followed by a series of analyses, both internal and external, which provide the context for development of the strategic issues. Specific strategies including strategic thrusts, action plans and targets are also clearly articulated. That plan, while cognizant of the Polytechnic past, is clearly focused on the future development within the context of the socio-cultural, political and economic, national and global environment in which it operates.

The change in strategic direction by Koforidua polytechnic is caused by change in position, magnitude and pattern of perspective. Planning in Koforidua Polytechnic is now cost-conscious more than ever before, and action plans and targets have been developed in close collaboration with the academia and administrators.

The change in strategic direction is a necessary measure to ensure the bright future of the Polytechnic. However, the challenge remains for the Polytechnic to ensure strategy implementation and to rise from financial difficulties and to strengthen collaboration. It is vital that the polytechnic does not lose sight of the strategic goals that focus on the key functions of the Polytechnic: teaching, learning and applied research.

The researcher proposes that for further research, a periodic evaluation of the Strategic Plan of 2010-2014 be conducted for the Polytechnic to identify its implementation challenges so that the evaluation will serve as input into the formulation of the third strategic plan.

\section{References}

Bergh, D. D. and Fairbank, J. F., (2002). Measuring and Testing Change in Strategic Management Research, Strategic Management Research, Vol. 23, No4, pp.359-366.

De Lourdes Machado, M., Farhangmehr, M. and Stover Taylor, J., (2004). The Status of Strategic Planning in Portuguese Higher Education Institutions: Trappings or Substance? Higher Education Policy, issue 17, pp.383-404.

Eurydice, (2010). Focus on Higher Education in Europe 2010: The Impact of the Bologna Process, European Commission, Brussels.

Gaston, P., (2010). The Challenge of Bologna: What United States Higher Education Has to Learn From Europe, and Why It Matters That We Learn It, Stylus Publishing, USA 
Ginsberg, A., (1988). Measuring and Modelling Changes in Strategy: Theoretical Foundations and Empirical Directions, Strategic Management Journal, Vol. 9, No. 6, pp.559-575.

Government of Ghana, Act 745, (2007). Polytechnic Act, 2007, Government Printer, Assembly Press, Accra.

Hayward, F. M., and Ncayiyana, D., (2003). A Guide to Strategic Planning for African Higher Institutions, Centre for Higher Education Transformation, South Africa.

Koforidua Polytechnic, (2005). Strategic Plan, 2005-2009, Koforidua Polytechnic, Koforidua.

Koforidua Polytechnic, (2010), Strategic Plan, 2010-2014, Koforidua Polytechnic, Koforidua.

Mintzberg, H., (1978). Patterns in Strategy Formation, Management Science, Vol.24, No.9, pp. 934-948.

Pevzner, M., (2006). A Case Study of Strategic Planning at Kent State University [online] Available from: http://www.irex.org/programs/uasp/CaseStudies 106/Pevzner.pdf[Accessed 2 September 2011]

Rajagopalan, N. and Spreitzer, G. M., (1997). Toward a Theory of Strategic Change: A Multi-lens Perspective and Integrative Framework, The Academy of Management Review, Vol.22, No.1, pp. $48-79$.
Rauhvargers, A., Deane, C. and Pauwels, W., (2009). Bologna Process Stocktaking Report. European Commission, Benelux.

Steiner, G. A., Miner J. B., and Gray E. R., (1986). Management Policy and Strategy MacMillan Publishing Company, New York.

Skilbeck, M., (1997). Higher Education in a Changing Environment: Regional, National and Transnational Issues, Tertiary Education and Management. Vol.3, No.2, pp.101-111.

Skilbeck, M., (2001). The University Challenged. A Review of International Trends and Issues with Particular Reference to Ireland, Higher Education Authority, Dublin.

Sursock, A. and Smidt, H., (2010). Trends 2010: A Decade of Change in European Higher Education; European University Association.

Ward, D. and Rivani, E., (2005). An Overview of Strategy Development Models and the Ward-Rivani

Model (online). Available- http://129.3.20.41/eps/get/ papers/0506/0506002.pdf (Accessed 3 September, 2011).

Yin, R. K., (1994). Case Study Research: Design and Methods, Sage, London. 